\title{
A Note from the Editors-Translators
}

ompared to many pre-revolutionary literary critics and their Marxist successors, the Russian Formalist critics are mostly straightforward and accessible writers - Viktor Shklovsky, for instance, has been extensively translated, and comes across clearly in English. Tynianov is a somewhat stranger bird. Though rarely dry and never pedantic, his style can swing wildly between chatty, lapidary, and downright opaque. In his introduction to the 1929 collection Archaists and Innovators, Tynianov acknowledged that his language was sometimes difficult and even unclear, but that "language does not merely transmit concepts, ...

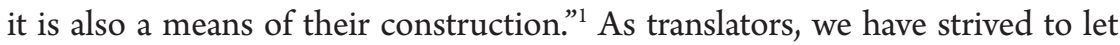
Tynianov be Tynianov, which meant maintaining a mostly layperson's register of language in conjunction with sudden bursts of inventive terminology.

This book is the first comprehensive collection of Tynianov's theoretical work in English, as well as the first time that more than two essays appear translated in one consistent voice: prior publications of his theoretical essays have been translated at different times and by different people and scattered throughout anthologies. ${ }^{2}$ Tynianov's sense of the complex interconnectedness of literary processes is mirrored in his own compact, sometimes strikingly poetic writing: the same metaphors, phrases, and literary examples keep turning up in

1 Iurii Tynianov, Arkhaisty i novatory [Permanent Evolution] (Leningrad: Priboi, 1929) includes "Literary Fact," “On Literary Evolution," “The Ode as Oratorical Genre," "Tyutchev and Heine," "Dostoevskii and Gogol (Toward a Theory of Parody)," "Interlude," and "On Khlebnikov."

2 Some of Tynianov's historical novels have been translated into English: Yuri Tynianov, Death of the Vazir-Mukhtar, trans. Susan Causey and Vera Tsareva-Brauner (London: LookMedia, 2018); Lieutenant Kijé; Young Vitushishnikov: two novellas, trans. Mirra Ginsburg (1990); Young Pushkin, trans. Anna Kurkina Rush and Christopher Rush (2007). 
unexpected corners, simultaneously exhibiting new facets and reminding the reader of their previous uses. A further motivation for translating these essays as a group was to demonstrate the remarkable coherence and consistency of Tynianov's thought (notwithstanding his occasionally slapdash terminology) over a wide range of material.

Tynianov's terminology invites further explanation. Certain termsmany of them rather unremarkable words with ordinary dictionary meanings, like shift or plan-acquire specific meanings in Tynianov's theoretical constructions. These terms pop up in different articles, in application to different material, throughout the collection-and the frequency of these recurrences was, again, a major motivation for undertaking a large-scale translation of Tynianov's work. To take one example: the concept of "shift" (covered by the noun smena-meaning both a change or alteration and a length of time, for example "the night shift" — and the related verb smeshchat' / smestit') can also mean to "displace" or "supplant"; the idea of "succession" is also present. Of the available options, "shift" is the most open-ended and capacious; we occasionally substitute one of the other options for clarity's sake. Recurring terms like these, along with less familiar Russian literary terms, have been marked in the texts and are defined in the Terms appendix at the end of the volume.

Just as he returns again and again to concepts like that of "shift" or "orientation," Tynianov makes frequent reference to a wide array of figures stretching across three centuries of Russian literature. The first part of the appendix ("Names and Terms") identifies writers and other figures who appear in multiple articles; if a name or term is not identified in a footnote, it will be marked with a superscript $\mathrm{N}$ or $\mathrm{T}$ and found in this section.

While we felt it crucial to give Tynianov a recognizable and consistent English voice, the copious quotations in his articles (primarily of poetry) were another matter. Wherever possible, we gratefully made use of excellent existing translations: James Falen's masterful, rhymed Eugene Onegin, Jesse Zeldin's rendition of Gogol's Selected Passages from Correspondence with Friends, or Clarence Brown and W. S. Merwin's classic translations of early Mandelstam. When left to our own devices with the poetry, we tended to prioritize Tynianov's theoretical aims; our goal was to demonstrate Tynianov's points about the function of poetic devices rather than to create freestanding poetic translations.

While this collection reproduces about half of the articles included in Archaists and Innovators, the main source for original texts was the exhaustively 
annotated Poetics. Literary History. Film (1977). ${ }^{3}$ Edited by Alexander and Marietta Chudakov, and Evgeny Toddes, this seminal volume remains the most comprehensive Russian edition of Tynianov's work and represents a truly heroic effort on the editors' part. As Marietta Chudakova recalls, they spent two years in the archives composing and assembling the notes (over 250 pages' worth), and another four years pushing the volume past the formidable, multitiered behemoth of Soviet censorship. While Tynianov was not himself subject to state repression, many of his contemporary subjects (Akhmatova, Mandelstam, Pasternak, and others) had become unprintable in the years following the initial publication of his articles. For example, Chudakova reminisced about an editor telling her to reduce the number of times Mandelstam was mentioned in the notes from seventeen to two, resulting in some peculiarly convoluted formulations ("compare a different assessment of these same features of the Serapions' prose by the author of 'A Conversation about Dante' [... ]"). ${ }^{4}$ Despite these compulsory verbal acrobatics, the notes to the 1977 edition are a priceless resource; we relied on them extensively in our work as translators and have gratefully translated some of them as notes to the English text of the articles.

The articles in this collection present Tynianov's "greatest hits" (his most frequently anthologized foundational theoretical statements like "Literary Fact" and "On Literary Evolution"), in company with denser, thornier works like "The Ode as an Oratorical Genre" and "On the Composition of Eugene Onegin," and lesser-known pieces that seem to address narrowly specialized topics: "Tyutchev and Heine" or "On the Screenplay." As its title indicates, Poetics. Literary History. Film groups the articles by discipline; by contrast, this collection is organized for the most part in chronological order, in an attempt to demonstrate the continuity of Tynianov's thought as it crisscrosses thematic, generic, and disciplinary boundaries. As each article shows, Tynianov never really wrote "just" about Tyutchev, or screenplays, or odes: while discussing concrete material, often in exacting and illuminating detail, Tynianov always has a larger theoretical point to make, using whatever material is closest at hand

3 Iurii Tynianov, Poetika. Istoriia literatury. Kino, eds. M. O. Chudakova, A. P. Chudakov, and E. A. Toddes (Moscow: Nauka, 1977), or PILK (as this volume is affectionately known in Russian), is the source for all of the articles translated here except for "On Khlebnikov." Henceforth, the volume will be referred to as PILK. Selected notes in this publication are by A. P. Chudakov $[A C]$; additional notes are by Yuri Tynianov $[Y T]$ and the translators [unmarked].

4 See "The Serapion Brothers. Almanac 1" [Serapionovy brat'ia. Almanakh I], in ibid., 449 $\mathrm{n} 8$. 
(see Daria Khitrova's introduction for an extended discussion of Tynianov's theoretical practice).

This collection aims to show Tynianov's place in the history of literary theory, while also pointing to the practical relevance of his thinking for literary analysis today. The literary scholar Lydia Ginzburg, who studied with Tynianov in the 1920s, later described the distinctive nature of Tynianov's thinking and its surprisingly broad applicability:

Tynianov's ideas, rather than being incontestable or irrevocable (that never happens), were applicable in a very enduring and tenable way. There are ideas, indeed very substantial ones, which function exactly as intended and move in a straight line from teacher to student. Then there are thoughts that spread out in circles: they can be influential in various contexts and at great distances from the article or book in which they are first suggested. This is how it worked with Tynianov's ideas. They generated new concepts, were applied and tested in practice. Using material, meanwhile, that Tynianov himself had not studied. Transplanted into a new environment, his conceptions continued working and bringing in new results. ${ }^{5}$

We hope very much that this most recent translation will take root and continue to bring in new results for students of literature all over the English-speaking world.

\author{
Ainsley Morse \\ Riverside, CA \\ Philip Redko \\ Cambridge, MA
}

August, 2018

5 Lidiia Ginzburg, "Tynianov—literaturoved," in Zapisnye knizhki (St. Petersburg: Iskusstvo-SPb, 2012), 447. 